\title{
Purification and Properties of a New endo-Cellulase from Robillarda sp. Y-20
}

\author{
Naohiro Yoshigi, ${ }^{*}$ Hajime TANiguchi ${ }^{\dagger}$ and Takashi SASAKI \\ National Food Research Institute, Ministry of Agriculture, Forestry and Fisheries, \\ 2-1-2, Kannondai, Yatabe, Tsukuba, Ibaraki 305, Japan \\ * Research \& Development Laboratories, Sapporo Breweries Ltd., 10, Okatohme, \\ Yaizu, Shizuoka 425, Japan
}

Received November 26, 1987

\begin{abstract}
A cellulolytic enzyme was purified from a crude enzyme preparation from Robillarda $\mathrm{sp}$. Y-20 by consecutive column chromatography. The purified enzyme was homogeneous on polyacrylamide gel electrophoresis and contained $10.5 \%$ carbohydrate as glucose. The enzyme had a molecular weight of 56,000 , an isoelectric point of 3.80 , an optimum $\mathrm{pH}$ of 5.0 , and an optimum temperature of $60^{\circ} \mathrm{C}$. It was stable from $\mathrm{pH} 4.0 \sim 7.0$ at $37^{\circ} \mathrm{C}$ for $1 \mathrm{hr}$ and below $50^{\circ} \mathrm{C}$ for $30 \mathrm{~min}$.

The amino-terminal amino acid sequence of the enzyme was $\begin{array}{lllllllllllllll}4 & 5 & 6 & 7 & 8 & 9 & 10 & 11 & 12 & 13 & 14 & 15 & 16 & 17 & 18\end{array}$ Tyr-Ala-Gly-Val-Ala-Glu-Ser-Ser-Gly-Glu-Phe-Gly-Val-Trp-Ser.

The enzyme was inactivated by $1 \mathrm{~mm} \mathrm{Fe} e^{3+}, \mathrm{Hg}^{2+}$, or $N$-bromosuccinimide. It was active on sodium carboxymethyl cellulose (CMC) and cellooligosaccharides (cellotriose to cellohexaose), but not on either cellobiose or microcrystalline cellulose (Avicel) under our assay conditions. The $\mathrm{Km}$ value of the enzyme for CMC was $0.060 \%$.
\end{abstract}

Cellulolytic enzymes have been purified from many microorganisms and their enzymatic properties have been investigated. One component of the cellulase system is $1,4-\beta$-Dglucan 4-glucanohydrolase [EC 3.2.1.4], sometimes called carboxymethyl cellulase (CMCase) or endo-cellulase. Robillarda sp. Y20 , isolated in our laboratory, is a fungus with sodium carboxymethyl cellulose (CMC) hydrolyzing activity in the culture filtrate higher than that of Trichoderma reesei QM9414, reaching 4.9-fold ${ }^{1)}$ and Ujiie and Sasaki reported the purification and enzymatic properties of one endo-cellulase, tentatively called CMCase II, and two $\beta$-glucosidases from a crude enzyme preparation. ${ }^{2)}$

We have isolated another cellulase component which acted on CMC, tentatively called CMCase I, from the same preparation from Robillarda sp. Y-20.

Here we report the purification and enzymatic properties of CMCase I, and discuss the differences between CMCases I and II.

\section{MATERIALS AND METHODS}

Materials. CMC was supplied by Daiichi Industrial Pharmaceutical Co., Ltd.; the degree of substitution was 0.51 . Cellooligosaccharides from cellobiose $\left(\mathrm{G}_{2}\right)$ to cellohexaose $\left(\mathrm{G}_{6}\right)$ were obtained from Seikagaku Kogyo Co., Ltd. and microcrystalline cellulose (Avical SF) from Asahi Chemical Inductry Co., Ltd. All other chemicals were commercial products of analytical grade.

Enzyme source. A crude enzyme powder of Robillarda sp. Y-20, prepared and furnished by Meiji Seika Kaisha, Ltd., was used as a starting material for the purification of the enzyme. This powder was prepared by $70 \%$ ethyl alcohol precipitation of the culture filtrate, followed by dialysis and lyophilization of the precipitated materials.

To whom reprint request should be addressed.

Abbreviations: $\mathrm{G}_{1}$, D-glucose; $\mathrm{G}_{2}$ to $\mathrm{G}_{6}$, cellooligosaccharides from cellobiose to cellohexaose; SDS, sodium dodecyl sulfate; NBS, $N$-bromosuccinimide; EDTA, ethylenediaminetetraacetic acid. 
Enzyme assay method. CMC-saccharifying activity was used as the standard assay of cellulase. The reaction mixture contained $0.05 \mathrm{ml}$ of enzyme solution, $0.2 \mathrm{ml}$ of $0.1 \mathrm{M}$ acetate buffer ( $\mathrm{pH} 5.0$ ), and $0.25 \mathrm{ml}$ of $1 \% \mathrm{CMC}$ solution. After incubation at $37^{\circ} \mathrm{C}$ for an appropriate period, the reducing sugar produced was measured by the method of Somogyi ${ }^{3)}$ and Nelson. ${ }^{4}$ One unit of the enzyme activity was defined as the amount that liberated reducing sugar equivalent to $1 \mu \mathrm{mol}$ of $\mathrm{D}$-glucose per min under our standard assay conditions.

Analytical methods. Protein content was measured by the method of Lowry et al. ${ }^{5}$ with bovine serum albumin as a standard. The absorbance at $280 \mathrm{~nm}$ was used for monitoring proteins in column effluents. The amount of carbohydrate was measured by the phenol-sulfuric acid method $^{6)}$ with D-glucose as a standard.

Electrophoresis. Polyacrylamide disc gel electrophoresis was done by the method of Davis ${ }^{7)}$ except that the running gel contained $0.125 \% \mathrm{CMC}$. After the electrophoresis, one gel was stained for protein with $0.4 \%$ Coomassie Brillant Blue R-250 and the other was stained for the enzyme activity by congo $\mathrm{red}^{8)}$ as follows: the gel was incubated in $0.1 \mathrm{M}$ acetate buffer ( $\mathrm{pH} \mathrm{5.0)}$ ) at $37^{\circ} \mathrm{C}$ for $30 \mathrm{~min}$, dipped in $0.2 \%$ congo red solution for $15 \mathrm{~min}$, and washed with $1 \mathrm{M}$ sodium chloride solution. The visualized bands were stabilized with $7.5 \%$ acetic acid. SDS-polyacrylamide gel electrophoresis was done by the method of Weber and Osborn. ${ }^{97}$ Samples were first treated at room temperature for $24 \mathrm{hr}$ in $1 \%$ SDS and $4.8 \%$ 2-mercaptoethanol. Electrofocusing was done on a polyacrylamide gel column as described by Wrigley $^{10}$ using Ampholyte of $\mathrm{pH}$ 2.5 5.0 (Pharmacia Fine Chemicals AB, Uppsala, Sweden) at a constant voltage of $400 \mathrm{~V}$ for $2.5 \mathrm{hr}$. Two sample gels each containing $42.4 \mu \mathrm{g}$ of protein were run simultaneously. After electrofocusing, one gel was stained for protein and the other was cut into $2.5 \mathrm{~mm}$ pieces, then extracted overnight with $1 \mathrm{ml}$ of deionized water. The enzyme activity and $\mathrm{pH}$ of each extract were measured.

Amino-terminal sequence analysis. Amino-terminal amino acid sequencing was done with an automated protein sequencer/PTH analyzer system (Model 477A/ 120A, Applied Biosystems).

Hydrolysis of soluble substrates. The reaction mixture, composed of $0.4 \mathrm{ml}$ of $1 \%$ substrate solution and $0.4 \mathrm{ml}$ of the enzyme solution $(0.32 \mathrm{U})$ in $0.01 \mathrm{~m}$ acetate buffer $(\mathrm{pH}$ 5.0 ), was incubated at $37^{\circ} \mathrm{C}$. At times, $200-\mu 1$ samples were withdrawn and heated at $100^{\circ} \mathrm{C}$ for $1 \mathrm{~min}$. After cooling, $20 \mu 1$ of the samples was used for high-performance liquid chromatography (HPLC), as described elsewhere, ${ }^{11}$ to identify each cellooligosaccharide produced by the enzyme action. The amounts of glucose and cellobiose produced from $\mathrm{CMC}$ were found by the peak area method. ${ }^{2 \text { ) }}$
Measurement of $\mathrm{Km}$ for CMC. A mixture of $0.25 \mathrm{ml}$ of $0.25 \sim 1.0 \% \mathrm{CMC}$ solution and $0.2 \mathrm{ml}$ of $0.1 \mathrm{M}$ acetate buffer ( $\mathrm{pH} \mathrm{5.0)}$ was equilibrated at $37^{\circ} \mathrm{C}$. The reaction was started by the addition of $0.05 \mathrm{ml}$ of the purified enzyme $(0.04 \mathrm{U})$ warmed to the same temperature. At times, $0.1-\mathrm{ml}$ samples were removed, and the reducing sugar liberated was measured by standard assay conditions. The $K m$ value was calculated from Lineweaver-Burk plots. ${ }^{13}$ )

\section{RESULTS}

\section{Purification of the enzyme}

The following procedures were done at $4{ }^{\circ} \mathrm{C}$ except that column chromatography was done at room temperature.

Step 1: Butyl-Toyopearl 650S column chromatography. The crude enzyme powder $(2 \mathrm{~g})$ was dissolved in $50 \mathrm{ml}$ of $0.01 \mathrm{M}$ acetate buffer $(\mathrm{pH}$ 5.0). The crude enzyme solution was centrifuged at $15,000 \mathrm{rpm}(27,300 \times g)$ for 15 min to remove insoluble materials. To the resultant supernatant $(48.5 \mathrm{ml})$, ammonium sulfate was added to $40 \%$ saturation. The suspension was left for $1 \mathrm{hr}$ and centrifuged to remove precipitated proteins. The supernatant $(52.0 \mathrm{ml})$, added to the same volume of $0.01 \mathrm{~m}$ acetate buffer ( $\mathrm{pH} 5.0)$, was divided into two equal parts. Each portion $(52.0 \mathrm{ml})$ was put on a Butyl-Toyopearl $650 \mathrm{~S}$ column $(1.5 \times 18 \mathrm{~cm})$ preequilibrated with $0.01 \mathrm{M}$ acetate buffer $(\mathrm{pH}$ 5.0 ) containing $20 \%$ saturation ammonium sulfate and eluted stepwise with the solutions shown in Fig. 1. The CMCase activity was eluted as two peaks (P-A, P-B), fractions belonging to the major peak (P-A) were combined, and ammonium sulfate was added to $80 \%$ saturation. After centrifugation, the precipitated proteins were dissolved in and dialyzed against $0.01 \mathrm{M}$ acetate buffer ( $\mathrm{pH} 5.0$ ).

Step 2: 1st DEAE-Toyopearl 650S column chromatography. The dialyzate $(12.1 \mathrm{ml})$ was put on a DEAE-Toyopearl 650S column $(1.5 \times 18.5 \mathrm{~cm})$ previously equilibrated with $0.01 \mathrm{M}$ acetate buffer $(\mathrm{pH} 5.0)$. Elution was done successively with $200 \mathrm{ml}$ of $0.01 \mathrm{M}$ acetate buffer ( $\mathrm{pH} 5.0$ ) [P-A1], $300 \mathrm{ml}$ of $0.01 \mathrm{M}$ acetate buffer ( $\mathrm{pH} 5.0$ ) containing $0.05 \mathrm{M} \mathrm{NaCl}$ [P-A2], $200 \mathrm{ml}$ of $0.01 \mathrm{M}$ acetate buffer $(\mathrm{pH} \mathrm{5.0)}$ containing $0.1 \mathrm{M} \mathrm{NaCl}$ [P-A3], and $200 \mathrm{ml}$ of 


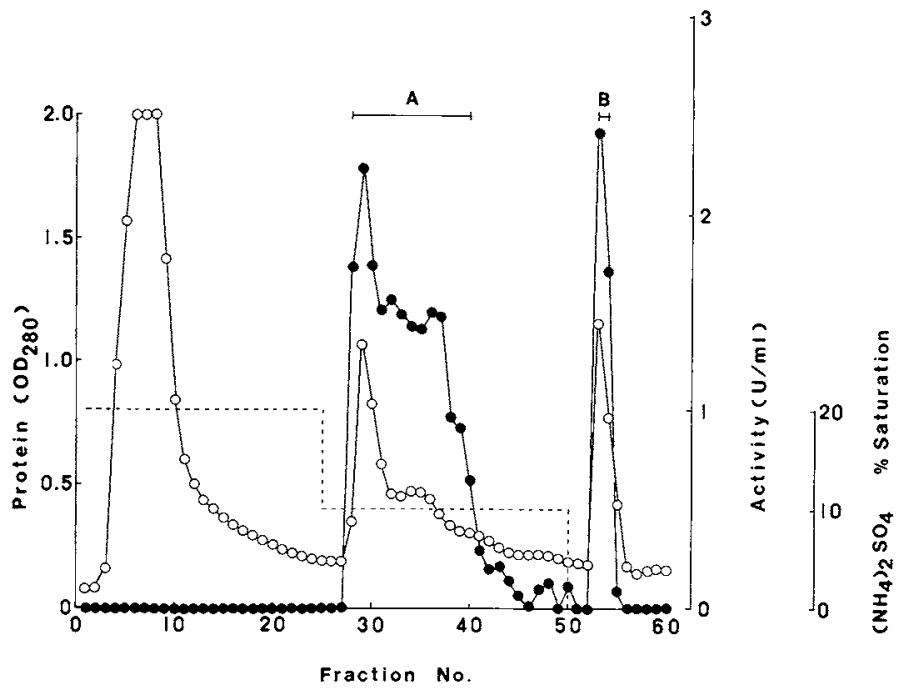

FIG. 1. A Typical Elution Profile of the CMC-Saccharifying Activity on Butyl-Toyopearl 650S Column Chromatography.

The flow rate was kept at $0.55 \mathrm{ml} / \mathrm{min}$. The fractions of $10 \mathrm{ml}$ each were collected and assayed for protein by the absorbance at $280 \mathrm{~nm}(\mathrm{O})$ and for CMC-saccharifying activity

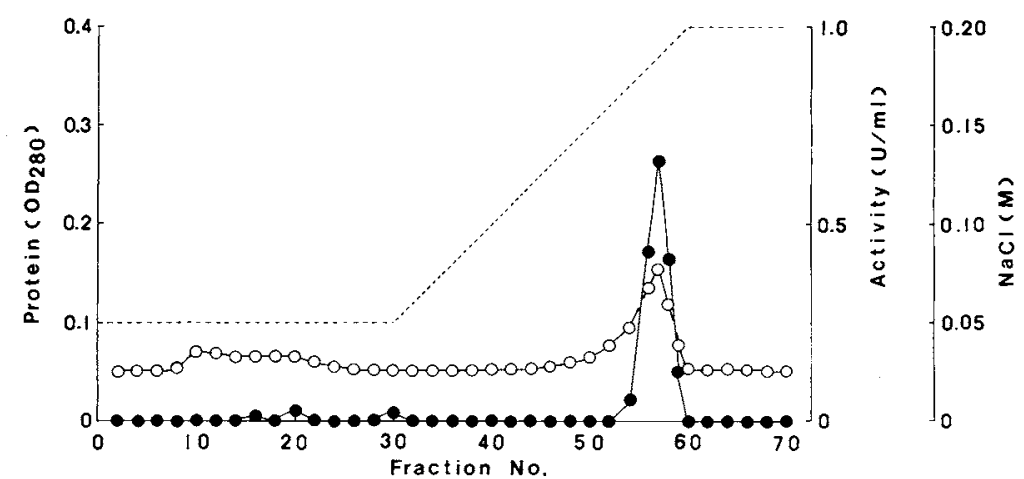

FIG. 2. Elution Patterns of the CMC-Saccharifying Activity on 2nd DEAE-Toyopearl 650S Column Chromatography.

The flow rate was kept at $1.38 \mathrm{ml} / \mathrm{min}$ and fractions of $5 \mathrm{ml}$ each were collected. Symbols are the same as in Fig. 1.

$0.01 \mathrm{M}$ acetate buffer $(\mathrm{pH} 5.0)$ containing $0.5 \mathrm{M}$ $\mathrm{NaCl}$ [P-A4]; the flow rate was kept at $5 \mathrm{ml}$ (=volume of one fraction) $/ 3.62 \mathrm{~min}$. The CMCase activity was eluted with each of the above four fractions (P-A1 4). When fractions belonging to each $\mathrm{CMCase}$ activity peak were pooled, dialyzed againt $0.01 \mathrm{~m}$ ace-

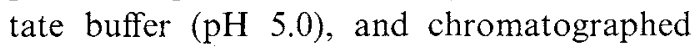
again on a DEAE-Toyopearl 650S column, only P-A3 gave a homogeneous CMCase.
Step 3: 2nd DEAE-Toyopearl 650S column chromatography. The dialyzate (P-A $3,70.8 \mathrm{ml}$ ) was put on a DEAE-Toyopearl $650 \mathrm{~S}$ column $(1.5 \times 18.5 \mathrm{~cm})$ preequilibrated with $0.01 \mathrm{M}$ acetate buffer ( $\mathrm{pH} 5.0$ ) containing $0.05 \mathrm{M} \mathrm{NaCl}$ and eluted by a linear salt gradient with the results shown in Fig. 2. The active fractions $(55 \sim 58)$ were combined and dialyzed against $0.01 \mathrm{M}$ acetate buffer $(\mathrm{pH} \mathrm{5.0)}$.

Table I summarizes the purification pro- 
Table I. Summary of the Purification Procedures

\begin{tabular}{lcccc}
\hline Step & $\begin{array}{c}\text { Total protein } \\
(\mathrm{mg})\end{array}$ & $\begin{array}{c}\text { Total activity toward CMC } \\
(\mathrm{U})\end{array}$ & $\begin{array}{c}\text { Specific activity } \\
(\mathrm{U} / \mathrm{mg})\end{array}$ & $\begin{array}{c}\text { Yield } \\
\%\end{array}$ \\
\hline Crude enzyme & 304 & 3705 & 12.2 & 100 \\
40\% $\left(\mathrm{NH}_{4}\right)_{2} \mathrm{SO}_{4}$ & 182 & 2855 & 15.7 & 77.1 \\
Butyl-Toyopearl 650S & 25.9 & 1048 & & 28.3 \\
P-A & 18.5 & 343 & 10.5 & 9.3 \\
P-B & 29.5 & 708 & 24.0 & 19.1 \\
P-A & & & & \\
80\% $\left(\mathrm{NH}_{4}\right)_{2} \mathrm{SO}_{4}$ & 6.74 & 109 & 3.5 & 0.63 \\
1st DEAE-Toyopearl 650S & 2.82 & 21.3 & 38.7 & 2.9 \\
P-A1 & 1.45 & 229 & 14.6 & 0.57 \\
P-A2 & 9.77 & 16.1 & 23.4 & 6.2 \\
P-A3 & & & 17.0 & 0.43 \\
P-A4 & 0.95 & & & \\
P-A3 & & &
\end{tabular}

cedures. The final purified enzyme (P-A3), called CMCase I, had a specific activity of 17.0 units per $\mathrm{mg}$ of protein in a final activity yield of $0.43 \%$, and was used in the following experiments as the purified enzyme.

\section{Homogeneity of the enzyme}

The purified enzyme showed a single protein band on polyacrylamide disc gel electrophoresis (Fig. 3A). This single band of protein had CMCase activity as shown in Fig. 3B. The crude enzyme preparation gave at least 9 CMCase activity bands (No. $1 \sim 9$ ) as shown in Fig. 3C. The purified enzyme (CMCase I) corresponded to band No. 3 in the crude enzyme preparation by its relative mobility.

\section{Molecular weight and carbohydrate content}

On SDS-polyacrylamide gel electrophoresis, the purified enzyme also gave a single band of protein as shown in Fig. 3D. The molecular weight was estimated to be 56,000 by comparison of its relative mobility on SDSpolyacrylamide gel electrophoresis with those of standard proteins; phosphorylase $B$ (mol. wt. 92,500), bovine serum albumin (mol. wt. 66,200), ovalbumin (mol. wt. 45,000), carbonic arhydrase (mol. wt. 31,000), soybean trypsin inhibitor (mol. wt. 21,500), and lysozyme (mol. wt. 14,400).

The carbohydrate content was calculated to

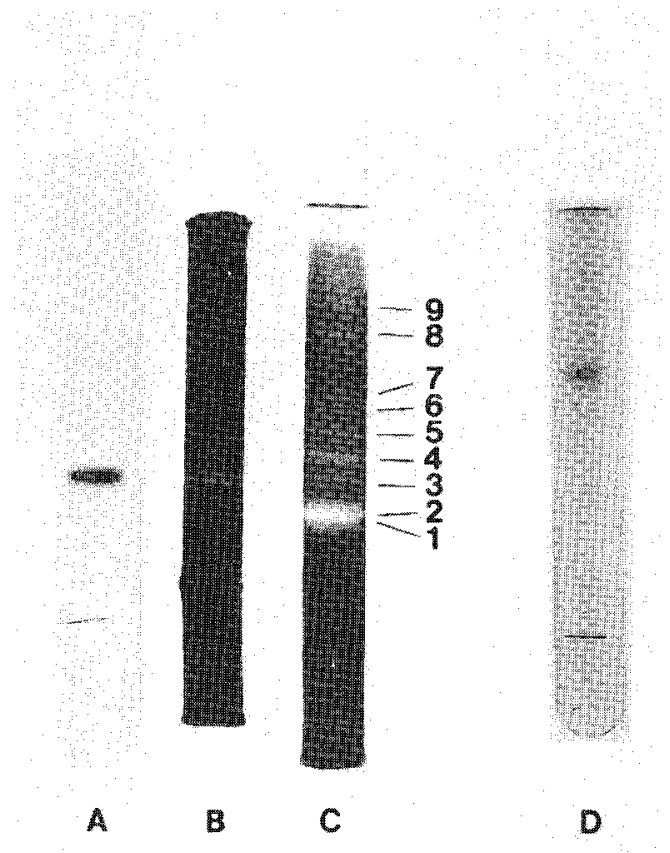

FIG. 3. Polyacrylamide Gel Electrophoresis.

A sample of the purified enzyme $(6.3 \mu \mathrm{g})$ or the crude enzyme preparation $(835 \mu \mathrm{g})$ was put on a gel column of $7.5 \%$ polyacrylamide and run at $4 \% \mathrm{C}$ under a constant current of $3 \mathrm{~mA}$ per tube for $2 \mathrm{hr}$. A, protein staining of the purified enzyme; $B$, activity staining of the purified enzyme; $C$, activity staining of the crude enzyme preparation; D, SDS-polyacrylamide gel electrophoresis was done in $7.5 \%$ polyacrylamide using $1.65 \mu \mathrm{g}$ of the purified enzyme. 
be $10.5 \%$ as glucose

\section{Isoelectric point}

The purified enzyme showed one major protein band that had CMCase activity, and 6 to 7 minor bands that had no CMCase activity. The isoelectric point of the major band was estimated to be $\mathrm{pH} 3.80$. The reason why the purified enzyme is isoelectrophoretically heterogeneous is unclear.

\section{Amino-terminal amino acid sequence}

The amino-terminal sequence of the enzyme was

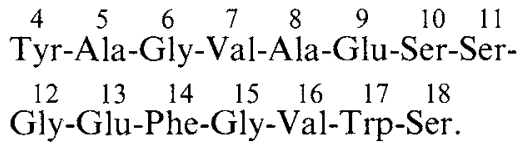

Sequencing was done twice with different enzyme preparations and exactly the same results were obtained. For the first three amino acids no specific amino acid was found in both sequencings.

\section{Optimum $p H$ and $p H$ stability}

The effects of $\mathrm{pH}$ on the activity of the purified enzyme were studied under standard assay conditions using citrate buffer $(0.1 \mathrm{M})$ at $\mathrm{pH} \quad 2.5 \sim 3.0$, acetate buffer $(0.1 \mathrm{M})$ at $\mathrm{pH}$ $3.5 \sim 6.0$, and Tris-maleate buffer $(0.1 \mathrm{M})$ at $\mathrm{pH}$ 6.5 8.0. CMCase I had its maximum activity at $\mathrm{pH} 5.0$, and about $75 \%$ of the maximum activity at $\mathrm{pH} 4.0$ and 6.5 (Fig. 4A).

Enzyme solution $(0.05 \mathrm{ml}, 0.04 \mathrm{U})$ was incubated with $0.2 \mathrm{ml}$ of buffers indicated above at $37^{\circ} \mathrm{C}$ for $1 \mathrm{hr}$. Then $0.05 \mathrm{ml}$ of the reaction mixture was withdrawn, and the re- maining activity was measured by the addition of $0.2 \mathrm{ml}$ of $0.5 \mathrm{M}$ acetate buffer (pH 5.0) and $0.25 \mathrm{ml}$ of $1 \% \mathrm{CMC}$ solution. The results are shown in Fig. 4B. The enzyme was completely stable between $\mathrm{pH} 4.0$ and 7.0. It was rapidly inactivated at $\mathrm{pHs}$ below 3.5 .

\section{Optimum temperature and temperature stability}

The effects of temperature on the activity of the purified enzyme were studied at various temperatures under the standard assay conditions. CMCase I had its maximum activity at $60^{\circ} \mathrm{C}$ (Fig. 5A).

Enzyme solution $(0.05 \mathrm{ml}, 0.04 \mathrm{U})$ was preincubated with $0.2 \mathrm{ml}$ of $0.1 \mathrm{M}$ acetate buffer $(\mathrm{pH} \mathrm{5.0)}$ at various temperatures for $30 \mathrm{~min}$. After the preincubation, the remaining activity was measured by the addition of $0.25 \mathrm{ml}$ of $1 \%$ $\mathrm{CMC}$ solution at $37^{\circ} \mathrm{C}$. CMCase I was completely stable at temperatures below $50^{\circ} \mathrm{C}$ (Fig. 5B). The enzyme retained about $50 \%$ of its original activity on heating at $60^{\circ} \mathrm{C}$, but was completely inactivated by heating at $65^{\circ} \mathrm{C}$, under the conditions used.

\section{Effects of metal ions and other reagents}

The reaction mixture containing $0.05 \mathrm{ml}$ of the enzyme solution $(0.04 \mathrm{U})$ plus $0.2 \mathrm{ml}$ of buffered metal or reagent solution (or buffer alone) was held at $37^{\circ} \mathrm{C}$ for $10 \mathrm{~min}$. Then the remaining activity was measured by the addition of $1 \% \mathrm{CMC}$ solution. The final concentration of each metal ion or reagent in the reaction mixture was $1 \mathrm{~mm}$. $\mathrm{Fe}^{3+}$ and $\mathrm{Hg}^{2+}$ inhibited the enzyme activity almost completely, and NBS did considerably (Table II). CMCase I was not inhibited by 1 mM EDTA or
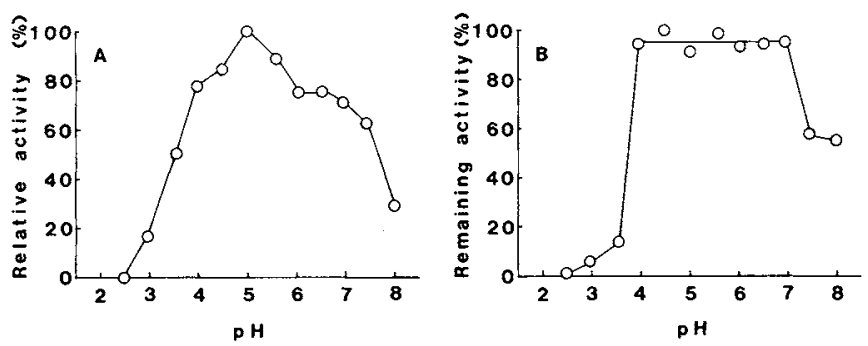

FiG. 4. Effects of $\mathrm{pH}$ on the Activity and Stability.

Experimental details are described in the text. A, effects on the activity; B, effects on the stability. 
iodoacetamide. This suggests that metals and sulfhydryl reagents are not essential for the enzymatic action, as are the cases with cellulases from Aspergillus niger ${ }^{14)}$ and Trichoderma viride. ${ }^{15,16)}$

\section{Hydrolysis products from soluble substrates}

The amounts of cellooligosaccharides produced from soluble substrates by the action of CMCase I are shown in Table III. The enzyme could attack neither $G_{2}$ nor Avicel. $G_{3}$ to $G_{6}$ were hydrolyzed to $G_{2}$ as the predominant

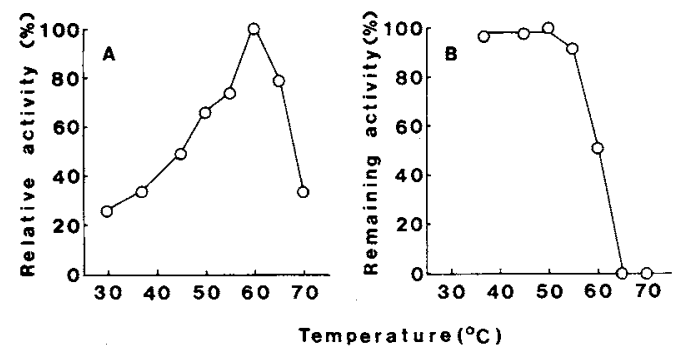

FIG. 5. Effects of Temperature on the Activity and Stability.

Experimental details are described in the text. A, effects on the activity; $\mathbf{B}$, effects on the stability. product. Transfer actions were also observed in the early stages of the reaction; $G_{4}$ and $G_{5}$ from $G_{3}, G_{5}$ and $G_{6}$ from $G_{4}$, and $G_{6}$ and $G_{7}$ from $G_{5}$ were formed. This enzyme hy-

Table II. Effects of Metals and Other Reagents ON THE CMCASE ACTIVITY

Metals were used as the chloride salt except for $\mathrm{Fe}^{3+}$ and $\mathrm{Ni}^{2+}$ sulfate.

\begin{tabular}{cc}
\hline Materials & $\begin{array}{c}\text { Remaining activity } \\
(\%)\end{array}$ \\
None & 100 \\
$\mathrm{Mg}^{2+}$ & 84 \\
$\mathrm{Fe}^{3+}$ & 1 \\
$\mathrm{Co}^{2+}$ & 60 \\
$\mathrm{Ba}^{2+}$ & 75 \\
$\mathrm{Zn}^{2+}$ & 64 \\
$\mathrm{Ca}^{2+}$ & 99 \\
$\mathrm{Ni}^{2+}$ & 89 \\
$\mathrm{Hg}^{2+}$ & 0 \\
$\mathrm{Cu}^{2+}$ & 71 \\
\hline $\mathrm{NBS}$ & 35 \\
EDTA & 105 \\
$\mathrm{SDS}$ & 107 \\
Iodoacetamide & 113 \\
\hline
\end{tabular}

Table III. Cellooligosaccharides Formation BY THE PURIFIEd ENZYME

\begin{tabular}{|c|c|c|c|c|c|c|c|c|}
\hline \multirow{2}{*}{ Substrate } & \multirow{2}{*}{$\begin{array}{l}\text { Time } \\
\text { (min) }\end{array}$} & \multicolumn{7}{|c|}{ Products (wt., \%) } \\
\hline & & $\mathrm{G}_{1}$ & $\mathrm{G}_{2}$ & $\mathrm{G}_{3}$ & $\mathrm{G}_{4}$ & $\mathrm{G}_{5}$ & $\mathrm{G}_{6}$ & $\mathrm{G}_{7}$ \\
\hline \multirow{4}{*}{$\mathrm{G}_{3}$} & 0 & & & 100 & & & & \\
\hline & 5 & 0.3 & 2.7 & 91.9 & 3.6 & 1.5 & & \\
\hline & 30 & 3.1 & 17.8 & 70.3 & 3.7 & 5.1 & & \\
\hline & 120 & 2.9 & 37.1 & 57.0 & 2.9 & & & \\
\hline \multirow{4}{*}{$\mathrm{G}_{4}$} & 0 & & & & 100 & & & \\
\hline & 5 & & 6.0 & 1.6 & 88.7 & & 3.8 & \\
\hline & 30 & 1.8 & 36.8 & 9.2 & 38.8 & 5.1 & 8.3 & \\
\hline & 120 & 2.2 & 61.0 & 26.3 & 8.0 & 2.6 & & \\
\hline \multirow[t]{4}{*}{$\mathrm{G}_{5}$} & 0 & & & & & 100 & & \\
\hline & 5 & & 4.1 & 9.9 & 3.8 & 82.2 & & \\
\hline & 30 & 0.7 & 20.4 & 25.6 & 9.3 & 29.4 & 7.0 & 7.5 \\
\hline & 120 & 1.1 & 47.0 & 32.9 & 14.0 & 5.0 & & \\
\hline \multirow{4}{*}{$\mathrm{G}_{6}$} & 0 & & & & & & 100 & \\
\hline & 5 & & 4.9 & 7.6 & 8.8 & 3.6 & 75.1 & \\
\hline & 30 & 0.7 & 19.6 & 23.4 & 25.1 & 10.9 & 20.2 & \\
\hline & 120 & 1.4 & 48.1 & 19.0 & 15.1 & 4.0 & 2.3 & \\
\hline \multirow[t]{3}{*}{$\mathrm{CMC}$} & 5 & 4.4 & 6.1 & & & & & \\
\hline & 30 & 4.0 & 15.1 & & & & & \\
\hline & 120 & 4.5 & 18.1 & & & & & \\
\hline
\end{tabular}


Table IV. A Summary of the Values of $K m$ and SPeCific ACtivity for CMC of EndoCELlulases from DifFERENT Fungi

\begin{tabular}{|c|c|c|}
\hline Enzyme source & $\begin{array}{l}K m \\
(\%)\end{array}$ & $\begin{array}{l}\text { Specific } \\
\text { activity } \\
\text { (U/mg) }\end{array}$ \\
\hline Robillarda sp. Y-20 CMCase I & 0.060 & 17.0 \\
\hline CMCase $\mathrm{II}^{2)}$ & - & 72.3 \\
\hline $\begin{array}{l}\text { Asperigillus niger cellulase }{ }^{14)} \\
\text { Trichoderma viride cellulases }\end{array}$ & 0.086 & 116.83 \\
\hline II- $\mathrm{A}^{151}$ & 0.081 & 29.83 \\
\hline$I I-B^{15)}$ & 0.096 & 4.95 \\
\hline $\operatorname{III}^{(6)}$ & 0.054 & 20.00 \\
\hline
\end{tabular}

drolyzed CMC to $G_{1}$ and $G_{2}$ (Table III). Certain amounts of oligosaccharides, probably containing carboxymethyl glucose, were detected on paper chromatography (data not shown) but were not detected by HPLC.

The relative initial hydrolysis rates for cellooligosaccharides were calculated from their decrease during the first $5 \mathrm{~min} ; 100$ minus residual substrate (mol, \%). Taking initial rate of $\mathrm{G}_{6}$ as 100 , CMCase I hydrolyzed more rapidly in the order of $G_{6}(100)>G_{5}$ (65) $>\mathrm{G}_{4}(40)>\mathrm{G}_{3}(22)$.

\section{$K m$ value for $C M C$}

Table IV summarizes the $K m$ values of CMCase I and some purified endo-cellulases from other fungal sources, with the specific activities of the individual enzymes. CMCase I was close to $T$. viride cellulase III in its action on CMC. The specific activity of CMCase II was about 4.25 times higher than that of CMCase I.

\section{DISCUSSION}

Ujiie and Sasaki isolated a cellulase component (CMCase II) from a crude enzyme preparation of Robillarda sp. Y-20 by isoelectric focusing chromatography and ion exchange chromatography. ${ }^{2)}$ In this report, we isolated a new cellulase component (CMCase I) by running hydrophobic chromatography and ion exchange chromatography. Final activity yields of CMCase I and CMCase II were
Table V. Comparison of Two CMCases FROM Robillarda sp. Y-20

\begin{tabular}{|c|c|c|}
\hline Properties & I & $\mathrm{II}^{2 \prime}$ \\
\hline Molecular weight & 56,000 & 59,000 \\
\hline Sugar content $(\%)$ & 10.5 & 0 \\
\hline $\mathrm{p} I$ & 3.80 & 3.5 \\
\hline Trp in protein & + & - \\
\hline Optimum pH & 5.0 & $4.0 \sim 5.0$ \\
\hline Stable $\mathrm{pH}$ & $4.0 \sim 7.0$ & $4.0 \sim 7.0$ \\
\hline $\begin{array}{l}\text { Optimum } \\
\text { temperature }\left({ }^{\circ} \mathrm{C}\right)\end{array}$ & 60 & 55 \\
\hline $\begin{array}{l}\text { Stable } \\
\text { temperature }\left({ }^{\circ} \mathrm{C}\right)\end{array}$ & $\sim 50$ & $\sim 50$ \\
\hline $\begin{array}{l}\text { Inhibition by } \\
\qquad(1 \mathrm{~mm})\end{array}$ & $\begin{array}{c}\mathrm{Fe}^{3+}, \mathrm{Hg}^{2+} \\
\text { NBS }\end{array}$ & $\mathrm{Hg}^{2+}, \mathrm{NBS}$ \\
\hline $\begin{array}{c}\text { Minimum substrate } \\
\text { of hydrolysis }\end{array}$ & $\mathrm{G}_{3}$ & $\mathrm{G}_{3}$ \\
\hline
\end{tabular}

$0.43 \%$ (Table I) and $30.6 \%,{ }^{2)}$ respectively, and it would seem that the former was a minor CMCase component, and the latter was a major one in the crude enzyme preparation.

The crude enzyme preparation of Robillarda sp. Y-20 gave at least 9 CMCase activity bands on polyacrylamide disc gel electrophoresis, and CMCase I corresponded to band No. 3 by its relative mobility (Fig. 3). CMCase II, purified by a different procedure from the same preparation by Ujiie and Sasaki, ${ }^{2)}$ perhaps corresponded to the band(s) No. 1 and/or 2 since the final activity yield was $30.6 \%$; the bands of No. 1 and 2 were very close to each other.

Table $\mathrm{V}$ is a comparison of the enzymatic properties of CMCases I and II. Though the two enzymes showed similarity in most of these properties, three main differences were observed; (1) CMCase I contained $10.5 \%$ carbohydrate as glucose while no carbohydrate moiety was associated with CMCase II. (2) CMCase I was almost completely inhibited by $1 \mathrm{mM} \mathrm{Fe}^{3+}$ while CMCase II wasn't. (3) CMCase I contained tryptophan in its amino acid sequence while no tryptophan was present in CMCase II by amino acid component analysis.

CMCase I could attack neither $G_{2}$ nor Avicel, but hydrolyzed cellooligosaccharides $\left(G_{3}\right.$ to $\left.G_{6}\right)$ to $G_{2}$ as the predominant product 
(Table III); the yields of $\mathrm{G}_{2}$ were about 37 to $61 \%$ within the test conditions. This result is different from the case of CMCase II; it produced $G_{1}$ as the main product from $G_{4}$ to $G_{6}$, and equal amounts of $G_{1}$ and $G_{2}$ from $G_{3}{ }^{2}{ }^{2}$ CMCase I showed not only hydrolysis but a transfer reaction for $G_{3}$ to $G_{5}$ (Table III). Cellooligosaccharides, the original substrate combined with $G_{1}$ or $G_{2}$, were produced by transglycosylation of CMCase I; especially for $\mathrm{G}_{3}$, transglycosylation seemed to be stronger than hydrolytic action in the early stages of the reaction. In case of the action for $\mathrm{CMC}$, CMCase I produced $G_{1}$ and $G_{2}\left(G_{2}>G_{1}\right.$, Table III) while CMCase II formed $G_{1}$ to $G_{3}$ $\left(G_{1}>G_{2}, G_{3}\right) .{ }^{2}{ }^{\prime}$ From these results, it is suggested that the action mode of CMCase $I$ is different from that of CMCase II. It seems that CMCase I is a cellobiose-producing cellulase from soluble substrates, while CMCase II is a glucose-producing enzyme. So, CMCase I is considered to play some part in cellulose degradation using the crude enzyme preparation that has high $\mathrm{CMC}$ hydrolyzing activity. ${ }^{1}$

Acknowledgments. The authors wish to express their thanks to Mr. T. Shigyo of Sapporo Breweries Ltd. for his analysis of the amino-terminal amino acid sequence, to Meiji Seika Kaisha, Ltd. for production of the crude enzyme preparation from Robillarda sp. Y-20, and to Daiichi Industrial Pharmaceutical Co., Ltd. for the gift of CMC.

\section{REFERENCES}

1) T. Nagai, Y. Kashiwagi, Y. Magae and T. Sasaki, Appl. Microbiol. Biotechnol., 20, 275 (1984).

2) M. Ujiie and T. Sasaki, Enzyme Microb. Technol., 9, 459 (1987).

3) M. Somogyi, J. Biol. Chem., 195, 19 (1952).

4) N. Nelson, J. Biol. Chem., 153, 375 (1944).

5) O. H. Lowry, N. J. Rosebrough, A. L. Farr and R. J. Randall, J. Biol. Chem., 193, 265 (1951).

6) M. Dubois, K. A. Gilles, J. K. Hamilton, P. A. Rebers and F. Smith, Anal. Chem., 28, 350 (1956).

7) J. Davis, Ann. New York Acad. Sci., 121, 404 (1964).

8) P. J. Wood, Carbohydr. Res., 85, 271 (1980).

9) K. Weber and M. Osborn, J. Biol. Chem., 244, 4406 (1969).

10) C. W. Wrigley, J. Chromatogr., 36, 362 (1968).

11) N. Yoshigi, T. Chikano and M. Kamimura, Agric. Biol. Chem., 49, 2379 (1985).

12) K. Kainuma, T. Nakakuki and T. Ogawa, $J$. Chromatogr., 212, 126 (1981).

13) H. Lineweaver and D. Burk, J. Am. Chem. Soc., 56, 658 (1934).

14) G. Okada, Agric. Biol. Chem., 49, 1257 (1985).

15) G. Okada, J. Biochem., 77, 33 (1975).

16) G. Okada, J. Biochem., 80, 913 (1976). 